\title{
ANALYSIS OF THE ROLE OF MODERATING SOCIO-CULTURAL PRESSURE FOR WEIGHT LOSS AND PHYSICAL CHANGES IN OBESE AND NORMAL WEIGHT ADOLESCENTS
}

\author{
Seyed Mohammad Hossein Hosseini Ravesh ${ }^{1}$ \\ ${ }^{1}$ Department of Physical Education and Sport Sciences, Zabol Branch, Islamic Azad University, Zabol, Iran, \\ Hhoseinir@yahoo.com \\ https://doi.org/10.29038/2220-7481-2020-01-107-115
}

\begin{abstract}
s
Topicality. Obesity is a global epidemic. Obesity is on the rise in developing countries due to changes in lifestyle. The Aim of the Research.This study aimed to compare body image problems and social-physical anxiety in obese and normal-weight adolescents by examining the moderating role of cultural social pressure for weight loss and physical change. Method. In this descriptive cross-sectional study, 70 adolescents obese and 72 adolescent girls with normal weight were selected through one-stage cluster sampling from high school students in Mashhad. Data collection and measurement tools included: high-sensitivity portable digital scales, Multidimensional Self-Relationships Questionnaire, Physical Social Anxiety Questionnaire, and Cultural Social Pressure Questionnaire. The groups were matched for education, gender, and age. Data were analyzed using SPSS 22 software. The Results of the Research. Results of multivariate analysis of variance showed that there was a significant difference in body image and physical and social anxiety between obese adolescents and normal weight adolescents. The results also showed that high cultural social pressure for weight loss and physical change has a significant role in increasing physical social anxiety. But it does not have a moderating role in the extent of body image problems and physical social anxiety. Obesity and high cultural social pressure for weight loss and physical change are important factors in increasing body image problems and physical and social anxiety. But cultural social pressure does not mitigate the role of obesity in increasing or decreasing body image problems and physical social anxiety. Conclusions. Therefore, it can be concluded that body image problems in obese individuals are more influenced by their body mass and not by the socio-cultural pressure for weight loss and body change.
\end{abstract}

Key words: Obesity, Body image, Physical social anxiety, Social-cultural pressure, Weight loss, Physical change.

Сидів Мохаммед Хоссейн Хоссейні Равеш. Аналіз значення стримання соціально-культурного тиску на підлітків із нормальною та надмірною масою тіла під час схуднення й фізичних змін. Актуальність. Ожиріння - це глобальна епідемія. Ожиріння зростає в країнах, що розвиваються через зміни способу життя. Мета дослідження. Це дослідження мало на меті порівняти проблеми з тілобудовою та соціально-фізичну тривожність у підлітків 3 ожирінням і нормальною вагою, вивчаючи помірковану роль соціального-культурного тиску для схуднення та фізичних змін. Методи. У дослідженні взяло участь 70 підлітків з ожирінням та 72 дівчини-підлітки з нормальною вагою, які були відібрані за допомогою одноетапного кластерного відбору з учнів середньої школи в Мешхеді. У процесі дослідження використано: високочутливі портативні цифрові ваги, багатовимірну анкету щодо взаємозв'язків, анкету фізичної соціальної тривоги та анкету культурного соціального тиску. Групи були зіставні за освітою, статтю та віком. Дані аналізували за допомогою програмного забезпечення SPSS22. Результати дослідження. Результати багатофакторного дисперсійного аналізу показали, що існує значна різниця щодо тілобудови та фізичної й соціальної тривожності в підлітків з ожирінням та підлітків із нормальною вагою. Результати також показали, що високий соціально-культурний тиск щодо схуднення й фізичних змін відіграє значну роль у збільшенні фізичної соціальної тривожності. Але це не $є$ досить суттєвим у масштабах проблем із тілобудовою та фізичною соціальною тривогою. Ожиріння й високий соціально-культурний тиск для схуднення та фізичних змін $є$ важливими факторами посилення проблем із зображенням тілобудови та фізичною й соціальною тривожністю. Але соціальнокультурний тиск не зменшує ролі ожиріння в збільшенні чи зменшенні проблем із тілобудовою та фізичною й соціальною тривожністю. Висновки. Тому можна зробити висновок, що проблеми 3 тілобудовою в людей 3 ожирінням більшою мірою впливають на їхню масу тіла, а не на соціокультурний тиск для схуднення та зміни тіла.

Ключові слова: ожиріння, тілобудова, фізична соціальна тривога, соціально-культурний тиск, схуднення, фізичні зміни.

Сидел Мохаммед Хоссейн Хоссейни Равеш. Анализ значения сдерживания социально-культурного давления на подростков с нормальной и избыточной массой тела во время похудения и физических изменений. Актуальность. Ожирение - это глобальная эпидемия. Ожирение растет в развивающихся странах из-за изменений в образе жизни. Цель исследования. Это исследование было нацелено на сравнение проблем с телосложением и социально-физической тревожностью у подростков с ожирением и нормальной массой тела путем изучения сдер- 
живающей роли культурно-социального давления для потери веса и физических изменений. Memoды. В этом перекрестном исследовании 70 подростков с ожирением и 72 девочки с нормальным весом были отобраны путем одностадийной кластерной выборки от учащихся старших классов в Мешхеде. Инструменты сбора и измерения данных включали высокочувствительные портативные цифровые весы, вопросник многомерных отношений в себе, вопросник физического социального беспокойства и вопросник культурного социального давления. Группы были сопоставимы по образованию, полу и возрасту. Данные проанализированы с использованием программного обеспечения SPSS 22. Результаты исследования. Результаты многомерного дисперсионного анализа показали, что существует значительная разница в телосложении, физической и социальной тревожности у подростков с ожирением и подростков с нормальным весом. Результаты также показали, что высокое социально-культурное давление для снижения веса и физических изменений играет важную роль в повышении физической социальной тревожности, но не играет сдерживающей роли в масштабах проблем с телосложением и физической социальной тревожностью. Ожирение и высокое социально-культурное давление для снижения веса и физических изменений являются важными факторами в увеличении проблем с социальной, и физической и социальной тревожностью. Но социальнокультурное давление не уменьшает роли ожирения в увеличении или уменьшении проблем с телосложением и физической социальной тревожностью. Bыводы. Таким образом, можно сделать вывод, что на проблемы с телосложением у людей с ожирением больше влияет их масса тела, а не социокультурное давление для потери веса и изменения тела.

Ключевые слова: ожирение, телосложение, физическая социальная тревожность, социокультурное давление, потеря веса, физические изменения.

Introduction. Obesity is a chronic and common disorder that is a predisposing factor for certain diseases such as cardiovascular disease, type 2 diabetes and some types of cancer. With the increasing prevalence of obesity, it is projected that by 2030,50 percent of the world's population will be obese [43]. Obesity is not only the cause of physical problems but as one of the interactions between the body and the psyche that has been observed in research literature, it is one of the causes of behavioral problems [41]. Research shows that obese children face many adverse behaviors and are more likely to use aggressive behaviors. Obesity has a two-way association with psychological distress and one's psychiatric status. In other words, many psychological problems as a primary and constant factor can cause obesity, and on the other hand, obesity itself can lead to many unpleasant psychological consequences and dissatisfaction with life. Obesity is positively and significantly correlated with internalized and extrinsic symptoms reported by parents [44] And in internal studies, Dehkordi reported that overweight and coping disorder in overweight boys was greater than in normal weight boys [6]. Therefore, one of the areas of research related to obesity is the study of the correlates and psychological treatments of obesity. Many external and internal studies have shown that psychological treatments are effective in reducing obesity. While this weight loss is minor in some cases. some believe that many obesity-related illnesses, such as diabetes, hypertension, and hyperlipidemia, have been significantly improved by slight $5 \%$ body weight reductions [4].

Considering the above findings and the many researches that confirm the correlation between psychological disorders and obesity, it is necessary to examine the problem of obesity from a psychological perspective. Looking at the research literature on obesity, we come to two very important concepts that have been studied in relation to this issue: body image and physical social anxiety. The body image can be defined as the subjective image of one's body size and shape (the perceptual dimension) and his or her sense of these physical (emotional dimensions). The link between obesity and body image has been established in many studies [20]. Singh, Ashok, Bino, Parskar [36], Bihomika [2] and Schwartz \& Brownell [35] attribute this to the incorrect estimation of body size and shape in obese individuals. on the other hand, severe cultural pressure on The slim, especially in Western societies, leading to the prevalence of body image dissatisfaction, especially among obese adolescents [17].

Another variable associated with obesity and little research has been done on it is physical social anxiety. Research has shown that physical social anxiety is associated with anxiety about the body, obesity, and eating disorders [2]. Physical social anxiety is one of the problems associated with dissatisfaction with the physical state and subset of social anxiety and occurs when a person feels that his or her physical characteristics are a potential source of ridicule or humiliation [25]. Every time a person perceives himself or herself as different from others, this means that he or she will evaluate his or her outward appearance negatively, may experience more social problems, receive weaker reactions from others, and thus exhibit poorer overall adaptation [32]. Because obese people have distorted estimates of their physical characteristics, and evaluate their appearance negatively, they are at risk for social anxiety, so that obese children are concerned about their body image and body image. Girls who are overweight are more likely to have social interaction problems than boys [14]. 
According to the findings, it is necessary to investigate the psychological problems of obese people, especially the two variables of body image and physical social anxiety. In recent years, however, researchers have found that the relationship between obesity and psychological problems is ambiguous and contradictory [21]. These findings point to the fact that most studies are looking for a simple link between obesity and psychological problems. Therefore, the researchers recommend that mediating and moderating variables be considered in examining the psychological problems of obese individuals.

Socio-cultural pressure in the general sense is the actual or potential social and cultural forces controlling or guiding human thought, behavior, or action in a particular direction. In a more limited sense, social-cultural pressure refers to public opinion. Many people think that sometimes socio-cultural pressure can affect people's sense of the world. Hence, some view the totality of the explicit and implicit, direct and indirect effects that the social and cultural environment exerts on the people in whom they live, as sociocultural pressure. The emergence of public opinion requires at least information, shared culture and human contact. The power of public opinion originates from the fact that certain behavior patterns are imposed by these thoughts and become behavioral norms [2]. Mass media, public opinion, fashion, advertising, and so on are important social and cultural forces to change the lifestyle and pressure on obese and overweight people to form inappropriate body image and strive to improve it [19]. The present study aimed to investigate the moderating role of cultural social pressure for weight loss and physical change in the incidence of physical image problems and physical and social anxiety in obese individuals. One of the influencing factors in behavioral and psychological problems such as body image problems and physical and social anxiety in overweight and obese women and girls, cultural social factors and extreme emphasis on fashion media and aesthetics of certain societies on excessive weight loss as [27; 41]. Recent research supports the social-cultural model of body image dissatisfaction in obese individuals. This model states that the more obese individuals feel the more pressured to lose weight, the more they are exposed to body image problems [22] and this dissatisfaction with body image results in increased physical social anxiety [15].

A 2011 study in several different countries found that ideal body image and body image dissatisfaction were influenced by parents, peers, the media, and religious attitudes. These socio-cultural factors even influence the type and amount of people's eating and physical activity. This study showed that cultural values and norms and messages received by the media, peers, and parents play an important role in ideal limb characteristics and as a result of body image dissatisfaction [30]. Numerous other studies have also shown that socio-cultural factors contributing to body image dissatisfaction include media pressure, peer pressure, and parental pressure [18]. However, numerous studies have also attempted to show that these three factors are culturally dependent and apply only to Western countries [23]. In other words, given the wide cultural differences between different societies, it is possible that obese individuals in one country may be less susceptible to self-esteem and increase physical social anxiety but not in another [29]. This approach has been supported by studies showing that Asian women are less physically dissatisfied with Western women and less likely to engage in weight loss behaviors [26]. But in recent years, Western culture about the ideal body is penetrating into Asian countries, including Iran, and the easiest way to identify the popularity of American and European films or to use fashion magazines among industry professionals, Fashion and clothing [31].

Given the widespread impact of socio-cultural factors, especially those of parents, peers, and the media, the present study hypotheses that body image and physical social anxiety in obese individuals are affected by cultural social pressure for weight loss and physical change. And these problems are tempered by the cultural social pressure to lose weight and change. Previous studies have reported that the vacuum is of interest, age, gender, and environment, with no specific attention being given to this group, nor to the differences in the culture of different countries. In addition, most of the internal research has been done in the field of medical sciences and psychology, and has received less attention from a physical education perspective. This study attempts to address the issue of obesity with an interdisciplinary perspective on the particular age and gender spectrum that most teachers and physical education teachers deal with from a different science perspective. It should be noted that due to the increasing influence of western social and cultural standards and ideals of physical activity in our country and the increasing pressure on obese people to gain lean body, it is necessary to recognize the psychological effects of these standards on individuals and psychological functioning. Their social, especially among obese young girls, is increasingly felt. Understanding the consequences of obesity and their exacerbated socio-cultural factors will lead to the design of more effective treatments and more careful planning to control obesity. However, there is no need for any internal studies to examine the social cultural 
pressure for weight loss and physical change in obese individuals. Finally, the theoretical and research foundations reinforce the idea that body image and social anxiety are different in obese and obese adolescents. Therefore, the purpose of the present study was to compare body image problems and physical social anxiety in Normal weight and obese adolescents with regard to the moderating role of cultural social pressure for weight loss and physical change.

Methodology. The present study is fundamental in terms of objectives and in terms of causal-comparative data collection. The statistical population of this study included all female adolescents studying in the school year of 2019, in high school in Mashhad, with the age range of 14-18 (50,000). The sample consisted of 70 obese and 72 normal weight girls who were selected by one-stage cluster sampling. first of them were selected randomly from seven districts of Mashhad city, then referring to all high schools of this area and weight measurement. And the height of the students, the obese were screened using the BMI. Health experts were measured every school. All students who were obese, a questionnaire survey was given. People with normal weight and obese subjects were matched for age and education groups and completed a similar questionnaire.

In the present study, since the sample studied were adolescents and the body ratios changed naturally during adolescence, so we defined the CDC as the z-score by age, or We defined over 30 as obese. BMI stands for Body Mass Index (BMI) is a statistical measure for comparing a person's weight and height. It is very simple to calculate and is used in many places to determine overweight and weight loss. Body mass index is obtained by dividing a person's weight in kilograms by the second power $(\mathrm{x})$ of his height in meters. In this index, individuals with a score above 30 are considered obese, with a range between less than 16 and more than 40 [9].

Measurement tools included high-sensitivity portable digital scales and a non-dilatable tape meter (for measuring body mass index), self-reported multidimensional relationship questionnaire, physical social anxiety questionnaire, and cultural social pressure questionnaire for weight loss and change.

During the study, after coordinating with the school authorities, students who appeared to have a body mass index above 30 were first used to measure height and weight by the school health officer to measure their height and weight. After determining their BMI, they completed the questionnaires if their BMI was above 30 and were willing to participate in the study. After data collection, they were entered into SPSS software and the results were discussed. In this study, descriptive and inferential statistics were used for data analysis. Descriptive statistics were used to show the status of the data such as mean and standard deviation. Multivariate analysis of variance was used to analyze the hypotheses in the inferential statistics section. For the purpose of the analysis, the Sociocultural pressure variable for weight loss and body change was transformed from the interval variable to the ordinal variable, so that the mean of Sociocultural pressure for weight loss and body change was calculated first for the research data and then They received lower than average scores as the group that had low pressure for weight loss and physical change, and those who had higher than average scores on cultural social pressure for weight loss and physical change, as the group who had high stress. To lose weight and have a change in body, they were grouped and so on Multivariate Analysis of Variance Analysis to Investigate the Main Effect of Weight (on Two Obese and Normal Weight Levels) and the Main Effect of Cultural Social Pressure on Weight Loss and Physical Change (with Two Levels of High and Low Pressure) on Components Body image and physical community anxiety as well as the interaction of weight effect and sociocultural stress were used for weight loss and physical change.

Findings. The mean age of the participants in this study was 14-18 years and the mean age of the obese group was 16,6 years and the mean age of the normal weight group was 16,2 years. The participants had a weight range of 25 to $110 \mathrm{~kg}$, The average weight of obese and normal weight group was $84 \mathrm{~kg}$ and $62 \mathrm{~kg}$, respectively. All participants were single. Multivariate analysis of variance was used to investigate the differences in body image problems in obese and overweight adolescents and to examine the moderating role of cultural social pressure on weight loss and body change in increasing or decreasing body image problems. Table 1 presents descriptive information on body image problems by obese and normal-weight individuals as well as by the level of cultural social pressure for weight loss and physical change.

As can be seen in Table 1, the average body image score in obese individuals is lower than in normalweight individuals. In addition, in both obese and normal-weight groups, people who experience high cultural social pressure for weight loss and physical change have lower body image scores than those who experience low cultural social stress. 
Mean and Standard Deviation of Body Image by Weight and Social Cultural Pressure for Weight Loss and Body Change

\begin{tabular}{|c|c|c|c|}
\hline Weight & The Amount of Pressure & Mean & SD \\
\hline \multirow{3}{*}{ Obese } & high pressure & 25,43 & 2,44 \\
\cline { 2 - 4 } & low pressure & 26,37 & 1,84 \\
\cline { 2 - 4 } & Total & 25,62 & 2,35 \\
\hline \multirow{3}{*}{ Normal weight } & high pressure & 27,16 & 2,90 \\
\cline { 2 - 4 } & low pressure & 27,96 & 2,47 \\
\cline { 2 - 4 } & Total & 27,76 & 2,59 \\
\hline \multirow{3}{*}{ Total } & high pressure & 25,89 & 2,66 \\
\cline { 2 - 4 } & low pressure & 27,67 & 2,44 \\
\cline { 2 - 4 } & Total & 26,78 & 2,69 \\
\cline { 2 - 4 } & & & \\
\hline
\end{tabular}

Examination of the assumptions of the multivariate analysis of variance showed that the assumption of homogeneity of variances is true using Levon's test $(\mathrm{F}=0,927$ and $\mathrm{P}>0,430)$. In addition, the normal distribution of the body image variable measured by the Kolmogorov-Smirnov test showed a normal distribution of this variable $(F=0,594$ and $Z=0,770)$. The results of multivariate two-factor variance analysis are presented in table 2. As can be seen in table 2, the effect of body weight was significant $(F=10,87$, $\mathrm{P}=0,001)$. That is, obese and normal-weight people differ in body image. According to table 1 , since the average obese person is less than the normal body weight, it can be said that obese people have more body image problems than the normal weight person. According to the results of table 2, the main effect of pressure was not significant $(\mathrm{P}=0,087$ and $\mathrm{F}=2,96)$. That is, there is no evidence of a difference between the two groups of high and low cultural social pressure for weight loss and physical change in both obese and normalweight groups in terms of body image. Also, according to the results of table 2, the interaction between weight and pressure factor was not significant $(\mathrm{P}=0,890$ and $\mathrm{F}=0,019)$. In other words, the amount of cultural social pressure for weight loss and physical change does not have a moderating role in increasing or decreasing body image problems.

Table 2

Multivariate Analysis of Variance for Body Image

\begin{tabular}{|c|c|c|c|c|c|c|}
\hline Components & $\begin{array}{c}\text { The Sum } \\
\text { of the Squares }\end{array}$ & $\begin{array}{c}\text { Degrees } \\
\text { of } \\
\text { Freedom }\end{array}$ & $\begin{array}{c}\text { Mean } \\
\text { Squares }\end{array}$ & F & $\begin{array}{c}\text { Significance } \\
\text { Level }\end{array}$ & Eta Coefficient \\
\hline weight & 66,69 & 1 & 66,69 & 10,87 & 0,001 & 0,073 \\
\hline $\begin{array}{c}\text { The amount } \\
\text { of pressure }\end{array}$ & 18,19 & 1 & 18,19 & 2,96 & 0,087 & 0,021 \\
\hline $\begin{array}{c}\text { Group } \\
\text { interaction and } \\
\text { pressure levels }\end{array}$ & 0,118 & 1 & 0,118 & 0,019 & 0,890 & 0,001 \\
\hline Error & 846,06 & 138 & 6,131 & & & \\
\hline Total & 102904,52 & 141 & & & & \\
\hline
\end{tabular}

To investigate the difference of physical social anxiety in obese and normal-weight adolescents and also to examine the moderating role of cultural social pressure for weight loss and physical change in increasing or decreasing physical-social anxiety in obese and normal-weight adolescents by multivariate analysis of variance. Variables were used. In table 3, descriptive information on physical social anxiety is presented in terms of obese and normal-weight individuals as well as the level of cultural social pressure for weight loss and physical change. As can be seen in table 3, the mean total score of physical social anxiety in obese individuals was higher than in normal-weight individuals, and in both obese and normal-weight groups, individuals who experienced high cultural social pressure to lose weight and experience physical change. They have higher levels of physical social anxiety than people who experience less cultural social stress. 
Mean and Standard Deviation of Physical Social Anxiety by Weight and Cultural Social Pressure for Weight Loss and Physical Change

\begin{tabular}{|c|c|c|c|}
\hline Weight & The Amount of Pressure & Mean & SD \\
\hline \multirow{3}{*}{ Obese } & high pressure & 24,23 & 6,50 \\
\cline { 2 - 4 } & low pressure & 20,30 & 6,65 \\
\cline { 2 - 4 } & Total & 23,44 & 6,67 \\
\hline \multirow{3}{*}{ Normal weight } & high pressure & 18,73 & 6,09 \\
\cline { 2 - 4 } & low pressure & 17,13 & 6,98 \\
\cline { 2 - 4 } & Total & 17,53 & 6,76 \\
\hline \multirow{3}{*}{ Total } & high pressure & 22,76 & 6,81 \\
\cline { 2 - 4 } & low pressure & 17,71 & 6,98 \\
\cline { 2 - 4 } & Total & 20,23 & 7,32 \\
\hline
\end{tabular}

Examination of hypotheses of multivariate analysis of variance analysis indicates that the assumption of homogeneity of variances is true using Levon's test $(\mathrm{F}=0,075$ and $\mathrm{P}>0,973)$. In addition, the normal distribution of the somatic social anxiety variable measured by the Kolmogorov-Smirnov test showed a normal distribution of this variable $(F=0,354$ and $\mathrm{Z}=0,929)$. The results of two-factor multivariate analysis of variance are presented in table 4 .

As can be seen in table 4, the effect of body weight was significant $(\mathrm{P}=0,002$ and $\mathrm{F}=10,167)$. That is, obese and normal-weight individuals differ in terms of physical and social anxiety. Taking into account table 3 , since the average obese person is higher than the normal body weight, it can be said that obese people have more physical social anxiety than the normal weight person. Also, based on the results of table 4, the main effect of pressure was also significant $(\mathrm{P}=0,044$ and $\mathrm{F}=4,130)$. That is, there is evidence of a difference between the two groups of high and low cultural social pressure for weight loss and physical change in terms of physical social anxiety. Considering table 3 because the average physical social anxiety of people who experience high stress for weight loss and physical change is higher than those who experience less stress, it can be said that high cultural social pressure for weight loss and physical change has a significant role. There is an increase in physical social anxiety. Based on the results of table 4, the interaction between weight and pressure factor was not significant $(\mathrm{P}=0,394, \mathrm{~F}=0,732)$. In other words, the extent of cultural social pressure for weight loss and physical change has no moderating role in increasing or decreasing physical social anxiety.

Multivariate Two-Factor Analysis of Variance for Physical Social Anxiety

Table 4

\begin{tabular}{|c|c|c|c|c|c|c|}
\hline Components & $\begin{array}{c}\text { The Sum } \\
\text { of the Squares }\end{array}$ & $\begin{array}{c}\text { Degrees } \\
\text { of Freedom }\end{array}$ & $\begin{array}{c}\text { Mean } \\
\text { Squares }\end{array}$ & F & $\begin{array}{c}\text { Significance } \\
\text { Level }\end{array}$ & $\begin{array}{c}\text { Eta } \\
\text { Coefficient }\end{array}$ \\
\hline $\begin{array}{c}\text { The amount } \\
\text { of pressure }\end{array}$ & 452,09 & 1 & 452,09 & 10,167 & 0,002 & 0,069 \\
\hline $\begin{array}{c}\text { Group } \\
\text { interaction } \\
\text { and pressure } \\
\text { levels }\end{array}$ & 183,65 & 1 & 183,65 & 4,130 & 0,044 & 0,029 \\
\hline Error & 32,535 & 1 & 32,535 & 0,732 & 0,394 & 0,005 \\
\hline Total & 6036,58 & 138 & 44,46 & & & \\
\hline $\begin{array}{c}\text { The amount } \\
\text { of pressure }\end{array}$ & 65734,00 & 142 & & & & \\
\hline
\end{tabular}

Conclusion. The purpose of this study was to compare body image problems and physical and social anxiety in normal weight and obese adolescents with regard to the moderating role of cultural social pressure for weight loss and physical change. The findings of this study showed that body image problems in obese adolescent girls were more than normal adolescent girls. This finding is in line with the findings of Singh, Bihomika [22], Dennis, Mohdbahar, Jesus, and Adiline [14] and Smolak [25]. The results can be inferred from the above studies that the reason for the high prevalence of body image problems in obese adolescents is the recent acceptance of lean forms of female body image that depict traits such as beauty, cleanliness, success, Fitness and health are all about weight loss. Researchers have shown that among both boys and girls, those with 
higher body mass index are more likely to lose weight, and this increase in body mass index with related structures such as body dissatisfaction, striving to lose weight, self-esteem. Low value and worry about being overweight and being dependent on a diet. On the other hand, according to research, the importance of physical attraction and body image among adolescents is more important than other parts of the population. During adolescence, people experience many physiological, psychological, and social changes that result from adolescence and can have potential effects on adolescent life. These physical changes are consistent with adolescent body image changes and believe that changes in physical appearance and increased introspection of adolescents may cause them to become extremely vulnerable to increased body dissatisfaction and image. A negative body will form in them. The findings showed that body image problems in obese and normal-weight female adolescents were not moderated by social cultural pressure for weight loss and body change.

Given the findings of the present study, the main effect of cultural social pressure for weight loss and physical change has no role in increasing body image problems of obese and overweight girls. This finding is inconsistent with research by Ashok, Allen, Byrne, McLean \& Davis, [28] and McCabe \& Ricciardi [21]. The result can be explained by the above studies, which is in line with the findings of the study, which can be attributed to the different social and cultural contexts of Iran with the communities in which the results are cited. Studies show that racial, cultural and social factors are effective in interpreting patterns of physical attractiveness. For example, in an intercultural study, Akiba [1] citing specific conditions and in his view the lack of mainstream media models in fashion and beauty in Iran, attributes this to the higher level of physical self-esteem of the students under study than the American students. The lack of official media propaganda in the field of fashion and beauty in Iran may have partly contributed to the immunity of the public from the commercial bombardment of fashion and beauty establishments overseas. Another reason that may explain this finding is inconsistent with previous research is how to assess cultural social pressure for weight loss and physical change.

The study measured social-cultural pressure from the media, father, mother, and best friend, and this tool may not have the high potential to assess the pressure applied to obese adolescent girls to lose weight. As for the media, there is no official media propaganda about fashion and beauty in Iran. On the other hand, given that lean body ideals are not as prevalent in Iran as many years ago, parents' body ideals are not as lean as their teenage children. The best friend may also not comment on the weight of a close friend unlike his less close friends. In addition, the results of the present study showed that there was no significant interaction between obesity and cultural social pressure for weight loss and physical change in body image problems. In other words, increasing or decreasing cultural social pressure for weight loss and body change has no role in increasing or decreasing obesity in obese individuals. So it can be said that body image problems in obese people are more influenced by their body mass than the amount of cultural social pressure to lose weight and change body.

The findings of the present study showed that physical social anxiety in obese female adolescents was higher than normal adolescent female adolescents. This finding is consistent with the research of Yousefi et al [44] and Blank et al [14] and Schwartz \& Brownell [33]. According to research by Lindwall and Lindgren [28], weight gain, weight loss indices and characteristics of physical fitness affect physical self-esteem and a sense of physical self-efficacy, and these factors will increase physical social anxiety. In addition, exercise has a profound effect on the level of physical social anxiety, which in obese individuals is extremely low in exercise and physical activity [10]. On the other hand, as mentioned in the findings section, obese adolescents have more body image problems than normal-weight adolescents, and one condition of social acceptance by others depends on one's physical structure and physical attractiveness, and therefore Worry about body image can contribute to increased social anxiety in obese individuals. Findings showed that high cultural social pressure for weight loss and physical change significantly increased physical social anxiety in obese adolescent girls. This finding is in line with the findings of Bino, Parskar, Levin and Piran [4] and Sandus, Cortez, and Straw [41].

The results can be inferred from the above studies that one of the variables that explain the reasons for the high level of physical dissatisfaction and social anxiety in women compared to men is the social cultural factors and the extreme emphasis on media advertising patterns. The fashion and beauty of some societies is overweight as a criterion of proportion in women. Although this pressure may be much lower in Iranian culture and society, it has a significant role in increasing physical social anxiety. However, according to the research findings, the interaction between weight factor and cultural social pressure for weight loss and physical change is not significant. In other words, high or low cultural social pressure for weight loss and physical change has no role in increasing or decreasing physical social anxiety in obese individuals. So it can be said that increasing 
or decreasing physical social anxiety in obese people is more influenced by their body mass, not because of the cultural social pressure to lose weight and body change, but because the social cultural pressure to lose weight and physical change also increase social anxiety. Physical has a role, so it can be said that each of these factors contributes separately to the development of physical social anxiety, and none modulates the other role in increasing or decreasing physical social anxiety. According to the research findings, it can be concluded that two factors of weight and the amount of cultural social pressure for weight loss and physical change have an important role in increasing the psychological problems of obese individuals. But neither of these factors moderates the other role in increasing or decreasing body image problems and physical social anxiety.

The limitations of the present study were the use of self-reporting tools and the limitation of the research sample to women, which did not allow comparisons of gender differences in the variables studied. The strength of this study was to investigate the moderating role of cultural social pressure in obese individuals and its role in causing problems in these subjects. Because behavior is complex and influenced by multiple variables, it is better to predict behavior by more variables than fewer variables.

\section{References}

1. Agliata, D. \& Tantelef-Dunn, S. (2004). The impact of media exposure on male's body image. Journal of Social and Clinical Psychology, 23(1), 7-22.

2. Akiba, D. (1998). Cultural variations in body esteem: how young adults in Iran and the United States view their own appearances. The journal of social psychology, 14, 539-40.

3. Ali Akbari Dehkordi, M. (2015). Comparison of Extraverted Disorders in Overweight Boys with Normal Weight Boys: Emphasis on Conduct Disorder, Journal of Health Psychology, No. 16, 30-30.

4. Allen, K. L.; Byrne, S. M.; McLean, N. J. \& Davis, E. A. (2008). Overconcern with weight and shape is not the same as body dissatisfaction: Evidence from a prospective study of pre-adolescent boys and girls. Body Image, 5, 261-270.

5. Assar Kashani, H., Roshan, R., Khalaj, H. R., Mohammadi, J. (2012). Comparison of physical misunderstanding and body image in obese, overweight and normal weight. Journal of Health Psychology, No. 2, 70-80.

6. Blank M. J., Berg, A. C. \& Melaville, A. (2006). Growing Comunity scholls: Therole of Cross-boundaryleder ship. whashington, DC: Coalition for Comunity Schools.

7. Brewer, B. W., Diehl, N. S., Cornelius, A. E., Joshua, M. D. \& Van Raalte, J. L. (2004). Exercising caution: Social physique anxiety and protective self-presentational behavior. Journal of Science and Medicine in Sport, $7(1), 47-55$.

8. Brownell, K. D. (1991). Dieting and the search for the perfect body: where physiology and culture collide. Behavior Therapy, 22, 1-12.

9. Burgess G., Grogan S. \& Buwitz L. (2006). Effects of a 6-week aerobic dance intervention on body image and physical self-perceptions in adolescent girls. Body image, 3, 57-66.

10. Clark, L. \& Tiggemann, M. (2006). Appearance culture in nine- to 12-year-old girls: Media and peer influences on body dissatisfaction [Electronic version]. Social Development, 15(4), 628-643.

11. Danis, A., Mohd Bahar, N., Isa, K. A. M. \& Adilin, H. Body image perspectives among adolescents in rural environment setting. Procedia-Social and Behavioral Sciences, 153, 436-442.

12. Dion, J., Blackburn, M. E., Auclair, J., Laberge, L., Veillette, S., Gaudreault, M., Vachon, P., Perron, M. \& Touchette, É. (2015). Development and etiology of body dissatisfaction in adolescent boys and girls. International Journal of Adolescence and Youth, 20(2), 151-166.

13. Faith, M. S., Calamaro, C. J., Dolan, M. S. \& Pietrobelli, A. (2004). Mood disorders and obesity. Current Opinion in Psychiatry, 17, 9-13.

14. Fitzsimmons-Craft, E. E., Harney, M. B., Koehler, L. G., Danzi, L. E., Riddell, M .K. \& Bardone-Cone, A. M. (2012). Explaining the relation between thin ideal internalization and body dissatisfaction among college women: The roles of social comparison and body surveillance. Body Image, 9, 43-49.

15. Gordon, K. H., Perez, M. \& Joiner, T. E. (2002). The impact of racial stereotypes on eating disorder recognition. International Journal of Eating Disorders, 32, 219-224.

16. Halliwell, E. \& Harvey, M. (2006). Examination of a sociocultural model of disordered eating among male and female adolescents. British Journal of Health Psychology, 11, 235-248.

17. Hart, E. A., Leary, M. R. \& Rejeski, W. J. (1989). The measurement of social physique anxiety in female. Journal of sport and exercise psychology, 11, 94-104.

18. Levine, M. P. \& Piran, N. (2004). The role of body images in the prevention of eating disorders. Body image, 1, $57-70$.

19. Lindwall, M. \& Lindgren, E. C. (2005). The effects of a 6-month exercise intervention program on physical selfperceptions and social physique anxiety in non - physically active Swedish girls. Psychology of sport and exercise, 6, 643-658. 
20. Louis, J. (2005). Personality tests. Translation: Mohammad Ali Besharat and Mohammad Habibnejad. Tehran: Aigie Publishing. First Edition

21. Lowry, R., Galuska, D. A., Fulton, J. E., Wechsler, H., Kann, L. \& Collins, J. L. (2000). Physical activity, food choice, and weight management goals and practices among U.S. college students. American Journal of Preventive Medicine, 181, 18-27.

22. McCabe, M. P \& Ricciardelli, L. A. (2001). Body image and body change techniques among young adolescent boys. European Eating Disorders Review, 9, 335-347.

23. McCabe, M. P., Mavoa, H., Ricciardelli, L. A., Schultz, J. T., Waqa, G. \& Fotu, K. F. (2011). Socio-cultural agents and their impact on body image and body change strategies among adolescents in Fiji, Tonga, Tongans in New Zealand and Australia. Obesity Reviews, 12, 61-67.

24. Mellor, D., McCabe, M., Ricciardelli, L., Yeow, J., Daliza, N. \& Mohd Hapidzal, N. F. (2009). Sociocultural influences on body dissatisfaction and body change behaviors. Body Image, 6, 121-128.

25. Moss, T. P. (2005). The relationships between objective and subjective ratings of disfigurement severity, and psychological adjustment. Body Image, 2, 151-159.

26. Motle, R. W. \& Conroy, D. E. (2000). Validity and factorial invariance of the social physique anxiety scale. Medicine and Science in sport \& Exercise, 32, 1007-1017.

27. Pope, A., McHairl, M., et al. And Karihada, A. (2014). Increase self-esteem in children and adolescents. Translated by Parisa Tajli, Roshd Publications, Tehran, p. 237.

28. Purgasem Gargari, H. Hamedbadzad, M. Seyed Sajjadi, N. Kouchavar, N. Karami, P. (2010). The Relationship between Body Mass Index and Nutritional Attitude in Tabriz Female High School Students Medical. Journal of Tabriz University of Medical Sciences, Vol. 23, 3, 29-24.

29. Rosenblum, G. D. \& Lewis, M. (1999). The relations among body image, physical attractiveness, and body mass in adolescence. Child Development, 70, 50-64.

30. Sadeghi, Gharai str., 2 Fathi, L. (2012). The Effectiveness of Cognitive Behavioral Therapy in the Treatment of Obesity Patients, Iranian. Journal of Psychiatry and Clinical Psychology, No. 2, 117-107.

31. Salehi, J. Rahmani, A. (1979). The Role of Social Anxiety in Exercise Determination of Motivation for Participation in Exercise Exercises, Journal of Sport Development and Motor Learning, No. 6.

32. Schwarz, M. B. \& Brownell, K. D. (2004) Obesity and body image. Body Image, 1, 43-56.

33. Shaw K., O'Rourke P., Del Mar C. \& Kenardy J. Psychological interventions for overweight or obesity. Cochrane Database of Systematic Reviews, 2005, Issue 2. Art. No.: CD003818.

34. Singh, M. M., Ashok, L., Binu, V. S., Parsekar, S. S. \& Bhumika, T. V. (2015). Adolescents and body image: a cross sectional study. Indian Journal of Pediatrics, 82(12), 1107-1111.

35. Sjoberg, L. R., Nilsson, W. K. \& Leppert, J. (2005). Obesity, Shame, and Depression in School-Aged Children: A Population-Based Study. Journal of the American Academy of Pediatrics, 116(3), 389-392.

36. Smolak, L. (2004). Body image in children and adolescents: Where do we go from here? Body Image, 1, 15-28.

37. Sobol-Goldberg, S \& Rabinowitz J. (2016). Association of childhood and teen school performance and obesity in young adulthood in the US National Longitudinal Survey of Youth. Preventive Medicine, 89, 57-63.

38. Sondhause, E. L., Kurtz, R. M. \& Strube, M. J. (2001). Body attitude, gender and selfoncept: a 30 years perspective. Journal of psychology, 135(4), 413-429.

39. Storch, E. A., Milsom, V. A., Debraganza, N., Lewin, A. B., Geffken, G. R. \& Silverstein, J. H. (2007). Peer victimization, psychosocial adjustment, and physical activity in overweight and at risk for overweight Youth. Journal of Pediatric Psychology, 32(1), 80-89.

40. Time, M. (2012). Predicting body image dissatisfaction based on psychological and socio-cultural factors. MSc thesis. Tabriz University.

41. Tsai, G. (2000). Eating disorders in the Far East. Eating and Weight Disorders, 5, 186-197. Ung, E. K. (2005). Eating disorders in Singapore; Coming of age. Singapore Medical Journal, 46, 254-256.

42. Villiers, M. D. (2006). Body image and dating relationships amongst adolescents. (Thesis of Master of Arts (psychology). University of Stellenbosch.

43. Yousefi, B., Tadiabi, and 2. Hosni, Z. (2010). The Effect of Gender and Exercise on Satisfaction with Physical Dimensions and Physical Social Anxiety among Students of Islamic Azad University District 11. Journal of Sport Management, No. 6, 136-121.

44. Yousefi, B., Hassani, Z. \& Shokri, O. (2009). Reliability and factor validity of the 7-item of social physique anxiety scale (SPAS-7) among university students in Iran. World Journal of Sport Sciences, 2(3), 201-204.

45. Zardasht, A. H., Besharat, M. A., Pourhossein, R., Bahrami Ehsan, A. H., Poursharifi, H. (2015). Comparing the Effectiveness of Interpersonal Relationship Therapy and Emotional Management on Weight Loss in Overweight and Overweight Women, Journal of Health Psychology, No. 14, 14-1.

Стаття надійшла до редакції 11.01.2020 p. 